eJKI | Vol. 8, No. 2, September 2019

Jurnal Kesehatan Islam

Email: jkesislam@unisma.ac.id

Home Page : http://riset.unisma.ac.id/index.php/jki

\title{
Perbedaan Tingkat Pengetahuan dan Pola Perilaku Pencegahan Diabetes Melitus Tipe 2 Setelah Penyuluhan Pola Aktivitas Fisik Pada Pendidik dan Tenaga Kependidikan Perguruan Tinggi di Malang
}

Eldina Afniasari Putri, Rizki Anisa, Erna Sulistyowati*

Fakultas Kedokteran Universitas Islam Malang (UNISMA)

\begin{abstract}
ABSTRAK
Pendahuluan: Sedentary life style merupakan salah satu faktor risiko terjadinya diabetes melitus tipe 2 (DMT-2) yang dapat dikendalikan. Hal ini dapat terjadi karena kurangnya pengetahuan mengenai pentingnya melakukan aktivitas fisik. Oleh karena itu pada penelitian ini diadakan penyuluhan kesehatan sehingga dapat meningkatkan pengetahuan serta merubah pola perilaku aktivitas fisik yang lebih sehat dan bertujuan untuk mencegah timbulnya penyakit DMT-2.
\end{abstract}

Metode: Penelitian ini merupakan studi eksperimental dengan rancangan one group pre test and post test design.

Responden adalah pendidik dan tenaga kependidikan Perguruan Tinggi di Malang yang berusia $\geq 40$ tahun dan tidak menderita diabetes melitus. Pengambilan data menggunakan instrumen soal pre test - post test untuk menilai tingkat pengetahuan dan kuesioner GPAQ (Global Physical Activity Questionnaire) untuk menilai perilaku aktivitas fisik. Sedangkan penyuluhan kesehatan sebagai intervensi. Analisa data kuantitatif menggunakan Wilcoxon test dan Sign test. Pada uji ini nilai $p$ adalah signifikansi, dikatakan bermakna bila $p<0,05$.

Hasil: Terdapat peningkatan rerata nilai pre test $(61,75 \pm 12,58)$ ke rerata nilai post test $(77,25 \pm 12,40)$ yang memiliki signifikansi ( $p$ 0,000). Jumlah responden sebanyak 40 orang yaitu 20 orang laki-laki dan 20 orang perempuan, dimana 19 orang mengalami peningkatan aktivitas fisik dengan signifikansi $(p 0,000)$. Usia dan pekerjaan diketahui tidak memiliki perbedaan dengan tingkat pengetahuan dan perilaku aktivitas fisik. Sedangkan jenis kelamin memiliki perbedaan dengan perilaku aktivitas fisik sebelum penyuluhan, namun tidak memiliki perbedaan setelah diberikan penyuluhan.

Kesimpulan: Terdapat perbedaan tingkat pengetahuan mengenai DMT-2 dan pentingnya melakukan aktivitas fisik setelah penyuluhan kesehatan sehingga meningkatkan pola perilaku aktivitas fisik sebagai upaya pencegahan DMT-2.

Kata kunci: penyuluhan kesehatan, tingkat pengetahuan, aktivitas fisik, diabetes melitus tipe 2.

\section{Differences in Knowledge Levels and Behavioral Patterns to Prevent Type 2 Diabetes Mellitus After Physical Activity Pattern Counseling to Lecture and Academic Staff in Malang University}

Eldina Afniasari Putri, Rizki Anisa, Erna Sulistyowati*

Faculty of Medicine, University of Islam Malang (UNISMA)

\begin{abstract}
Background: Sedentary life style is one of the risk factor for type 2 diabetes mellitus (DMT-2). It occurs due to a lack of knowledge about the importance of physical activity. Therefore, in this study, health counseling was held, so it could increase knowledge and change the behavior pattern of healthier physical activity. Moreover, it aimed to prevent DMT-2 disease.

Method: This research is an experimental study with one group pre test and post test design. Respondents are lecturer and academic staff in Malang University which are 40 years old and not suffering from diabetes mellitus. Data collecting used the pre test - post test instrument to assess the level of knowledge and used the GPAQ (Global Physical Activity Questionnaire) to assess physical activity behavior. Meanwhile, health counseling is an intervention. Quantitative data analyzed by Wilcoxon test and Sign test. In this test, the $p$ value is significant, $(p<0,05)$.

Result: There was an increasing of the pre-test meanvalue $(61,75 \pm 12.58)$ to post-test meanvalue $(77,25 \pm 12.40)$ which was significant $(p 0,000)$. The number of respondents was 40 people, they are 20 men and 20 women, which 19 people of them experienced a significantly increasing of physical activity had $(p 0,000)$. Age and occupation were known to have no difference with the level of knowledge and behavior of physical activity. Meanwhile, gender had difference with physical activity behavior before the counseling, but had no difference after being given the counseling.

Conclusion: There are differences in the level of knowledge about DMT-2 and the importance of carrying out physical activity after health counseling so as to increase the pattern of physical activity behavior as an effort to prevent DMT-2.
\end{abstract}

Keyword: health education, knowledge level, physical activity, type 2 diabetes mellitus.

*Correspondeing author : 
Erna Sulistyowati, dr., M.Kes., PhD

Jl. MT. Haryono 193 Malang City, East Java, Indonesia, 65144

e-mail : ernafkunisma@gmail.com, phone: 0341578920

\section{PENDAHULUAN}

Pada era globalisasi saat ini terjadi perubahan pola perilaku masyarakat salah satunya penurunan aktivitas fisik. Sedentary life style terjadi pada semua tingkatan usia sebagai akibat dari perkembangan teknologi dan dunia digital yang tumbuh semakin pesat. Teknologi yang berkembang juga dapat membantu kelangsungan pekerjaan manusia sehingga akan mempengaruhi dunia kerja yang semakin ringan dan tidak membutuhkan gerak tubuh maksimal. ${ }^{1}$

Faktor pekerjaan tertentu dapat mempengaruhi aktivitas fisik, salah satunya pada pekerjaan pendidik dan tenaga kependidikan yang tidak membutuhkan aktivitas fisik banyak dalam bekerja. Sepanjang hari dosen hanya duduk dan berdiri ketika mengajar, terlebih dengan adanya perkembangan teknologi dan kemudahan akses digital yang dapat mempermudah menyelesaikan pekerjaannya. ${ }^{1}$ Misalnya para dosen dan karyawan akan lebih memilih menggunakan lift daripada naik tangga, serta lebih menggunakan akses internet dan surat elektronik (email) untuk mengirim surat daripada pergi ke kantor pos. Hal tersebut cenderung membuat para dosen dan karyawan kurang aktif dalam bergerak dan kurang memberikan kesempatan untuk melakukan aktivitas fisik. ${ }^{1,2}$

Aktivitas fisik yang rendah dapat menjadi faktor risiko penyakit kronis salah satunya diabetes melitus tipe 2 (DMT-2) yang ditandai dengan peningkatan kadar gula darah dan peningkatan kadar HbA1c. ${ }^{3}$ Data World Health Organization (WHO) menyebutkan pada tahun 2014 sebanyak $8,5 \%$ orang dewasa berusia diatas 18 tahun menderita diabetes dan hampir semua kematian yang disebabkan oleh glukosa darah tinggi terjadi sebelum usia 70 tahun. Pada tahun 2016 dilaporkan bahwa diabetes adalah penyebab langsung 1,6 juta kematian dan diperkirakan bahwa diabetes adalah penyebab utama ketujuh kematian di dunia. ${ }^{4}$

Saat melakukan aktivitas fisik, glukosa yang disimpan di dalam otot akan digunakan dan ketika cadangan glukosa otot sudah berkurang maka otot akan mengambil glukosa di dalam darah sehingga glukosa darah dapat menurun. ${ }^{3}$ Hal ini diperkuat dengan penelitian yang dilakukan oleh Trisnawati dan Setyorogo (2013) yang mengungkapkan bahwa umur, riwayat keluarga, aktivitas fisik, tekanan darah, dan stress berhubungan dengan kejadian DMT-2. ${ }^{5}$ Oleh karena itu masyarakat yang memiliki faktor risiko tersebut harus lebih berhati-hati dan peduli terhadap hal ini sehingga dapat mengatur pola aktivitas fisik yang sehat.

Tingkat pengetahuan mengenai pola aktivitas fisik yang sehat dapat mempengaruhi pola perilaku masyarakat sehingga lebih peduli terhadap kesehatannya. Berdasarkan penelitian yang dilakukan oleh Goenawan et al, (2018) menyatakan bahwa tingkat pengetahuan akan pentingnya aktivitas fisik pada staf Perguruan Tinggi di Bandung cukup tinggi, namun pengetahuan mengenai durasi dan frekuensi ketika berolahraga masih rendah. Hal ini dikhawatirkan bahwa sumber informasi yang diperoleh kurang benar sehingga terjadi

kesalahpahaman informasi. ${ }^{6}$ Maka dari itu diharapkan penyuluhan kesehatan mengenai aktivitas fisik dapat meningkatkan pemahaman yang nantinya mempengaruhi pola perilaku aktivitas fisik yang sehat.

Berdasarkan hal tersebut inilah yang menjadi alasan untuk dilakukan penelitian sekaligus sebagai upaya promosi kesehatan berupa penyuluhan kesehatan melalui media sosial kepada pendidik dan tenaga kependidikan Perguruan Tinggi di Malang sebagai upaya pencegahan penyakit diabetes melitus tipe 2. Media sosial dipilih sebagai sarana penyuluhan karena seiring dengan perjalanan era globalisasi yang semakin maju, media sosial dapat dimanfaatkan untuk mensyiarkan ilmu kesehatan.

\section{METODE}

\section{Desain, Waktu dan Tempat Penelitian}

Penelitian ini menggunakan studi eksperimental jenis pra eksperimen dengan rancangan one group pre test and post test design, dilaksanakan di Perguruan Tinggi Malang pada bulan Agustus 2020. Penelitian ini telah disetujui oleh Komisi Etik Penelitian Kesehatan Rumah Sakit Islam Malang dengan No. 31/VII/2020/KEPK.RSI UNISMA.

\section{Populasi dan Instrumen Penelitian Populasi Penelitian}

Sampel yang akan dijadikan subjek penelitian adalah responden yang memenuhi kriteria inklusi sebagai berikut 1) bersedia menjadi responden, 2) berprofesi sebagai pendidik dan tenaga kependidikan (tendik) Perguruan Tinggi di Malang, 3) berusia $\geq 40$ tahun, 4) tidak menderita diabetes melitus.

\section{Instrumen Penelitian GPAQ (Global Physical Activity Questionnaire) WHO}

Kuesioner ini terdiri dari enam belas butir pertanyaan dan memiliki empat bagian yaitu aktivitas saat belajar atau bekerja, perjalan dari tempat ke tempat, aktivitas yang bersifat rekreasi, serta aktivitas menetap (sedentary behavior). Rincian pertanyaan kuesioner dapat dilihat pada data Supplementary 1. Penilaian aktivitas fisik dengan mengklasifikasikan perhitungan berdasarkan MET (Metabolic Equivalent) menit per minggu. Kemudian hasil akan diklasifikasikan kedalam tingkat aktivitas fisik. ${ }^{7}$ Perhitungan dapat dilihat pada Rumus 1 berikut.

$$
\begin{gathered}
{[(\mathrm{P} 2 \times \mathrm{P} 3 \times 8)+(\mathrm{P} 5 \times \mathrm{P} 6 \times 4)+(\mathrm{P} 8 \times \mathrm{P} 9 \times 4)+} \\
(\mathrm{P} 11 \times \mathrm{P} 12 \times 8)+(\mathrm{P} 14 \times \mathrm{P} 15 \times 4)]=\mathrm{MET}
\end{gathered}
$$




\section{Rumus 1. Perhitungan Skor Aktivitas Fisik Berdasarkan Metabolic Equivalent menurut analysis guide dari kuesioner GPAQ versi 2}

Pada Rumus 1 tersebut $\mathrm{P}$ merupakan nomor pertanyaan, 8 adalah koefisien aktivitas fisik tinggi dan 4 adalah koefisien aktivitas fisik sedang. Sedangkan klasifikasi aktivitas fisik dapat dilihat dalam Tabel 1 berikut.

Tabel 1. Klasifikasi Hasil Penilaian GPAQ (Global Physical Activity Questionnaire) versi 2

\begin{tabular}{cc}
\hline MET & Kategori \\
\hline MET $>3000$ & Tinggi \\
\hline $3000>$ MET $\geq 600$ & Sedang \\
\hline $600<$ MET & Rendah
\end{tabular}

Keterangan: Tabel 1 merupakan klasifikasi hasil penilaian GPAQ versi 2. Tabel ini menjelaskan penilaian aktivitas fisik dibagi menjadi kategori rendah, sedang dan tinggi.

\section{Soal Pre Test dan Post Test}

Soal pre test dan soal post test merupakat alat ukur tingkat pengetahuan. Instrumen ini terdiri atas sepuluh butir pertanyaan dengan<pilihan jawaban ganda a, b, c dan d meliputi lima pertanyaan seputar diabetes melitus dan lima pertanyaan mengenai cara pencegahaan diabetes melitus dengan melakukan aktivitas fisik. Rincian soal pre test dan post test dapat dilihat pada data Supplementary 2.

Tahapan Penelitian

Uji Keterbacaan, Validitas dan Reliabilitas

Uji keterbacaan, validitas dan reliabilitas kuesioner dilakukan kepada 30 orang pendidik dan tenaga kependidikan diluar sampling sebagai kriteria minimal pengambilan data untuk analisa statistik. ${ }^{8}$ Saat dilakukan uji coba pengerjaan kuesioner, responden mengerjakan kuesioner paling sebentar selama tujuh menit dan paling lama yaitu dua puluh menit. Hasil validitas menyatakan bahwa semua pertanyaan dalam kuesioner adalah valid dengan nilai validitas $>0,296$ ( $\mathrm{R}$ tabel) dan memiliki nilai hasil reliabilitas atau cronbach's alpha $>0,88$ yaitu sangat reliabel pada setiap pertanyaan kuesioner. ${ }^{9}$

\section{Penentuan Responden Penelitian}

Pada awal penelitian dilakukan distribusi formulir skrining untuk mendapatkan responden. Jumlah responden minimal berdasarkan Morgan and Krecjie Table, dimana populasi pada penelitian ini berjumlah 249 pendidik dan tenaga kependidikan perguruan tinggi di Malang yang berusia $\geq 40$ tahun. Sehingga kriteria sampel minimalnya berjumlah 152 pendidik dan tenaga kependidikan perguruan tinggi di Malang yang memenuhi kriteria inklusi yang dapat dilihat pada data Supplementary 3.

Distribusi formulir skrining tersebut menggunakan pesan pribadi di WhatsApp dengan memberi penjelasan sebelum persetujuan untuk mengikuti penelitian secara sukarela. Pendistribusiannya dilakukan selama tiga hari berturut-turut dengan melakukan follow up kepada calon responden yang belum merespon. Pada tahap ini didapatkan sejumlah 59 sampel yang bersedia mengisi formulir skrining. Namun setelah dikonfirmasi ulang serta diminta untuk mengisi lembar informed consent didapatkan sebanyak 40 responden yang masuk kriteria inklusi. Perjalanan alur penelitian untuk mendapatan responden dapat diamati pada Gambar 1 berikut ini.

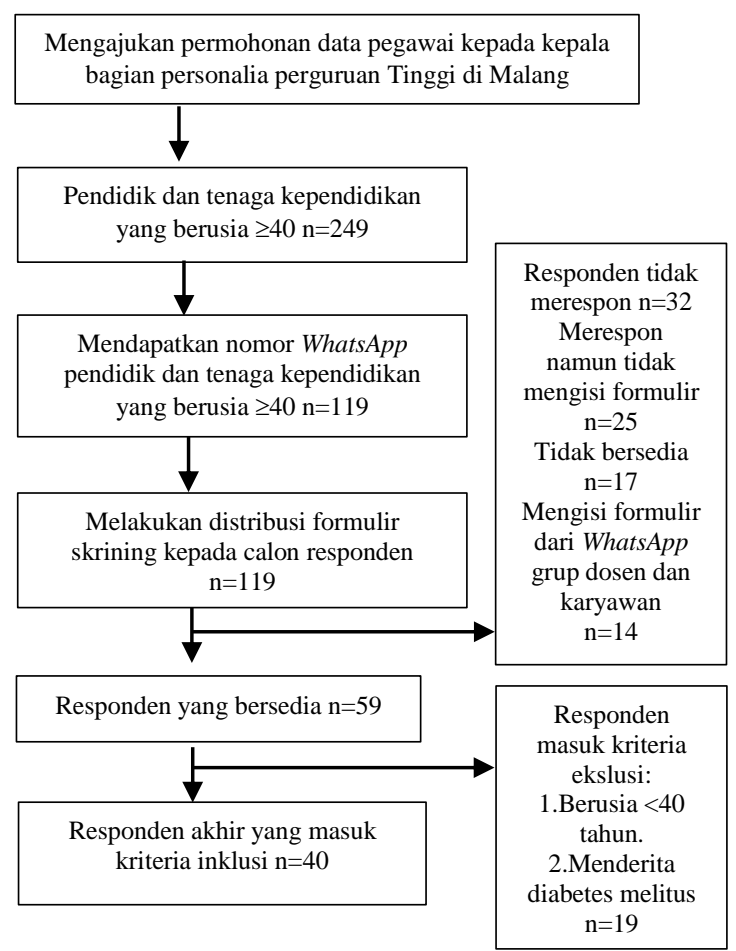

Gambar 1. Alur Penentuan Responden Penelitian Keterangan: Gambar 1 menjelaskan alur penentuan responden penelitian didapatkan sejumlah 40 sampel yang masuk kriteria inklusi.

Pengambilan Data Pre Test dan Kuesioner Awal

Pengambilan data pre test dan kuesioner awal dilakukan bersamaan dengan mendistribusikan link google form di grup WhatsApp untuk mengetahui perilaku aktivitas fisik responden sebelum diberikan perlakuan dan sejauh mana pengetahuan mereka mengenai penyakit diabetes melitus tipe 2 .

\section{Penyuluhan Kesehatan}

Penyuluhan kesehatan dilakukan menggunakan media sosial yaitu grup WhatsApp dengan memberikan infografis serta video edukasi. Infografis dapat dilihat pada data Supplementary 4 sedangkan video edukasi dpat dilihat pada Supplementary 5. Intervensi penyuluhan diberikan sebanyak tiga kali, pada tahap awal diberikan infografis berupa penjelasan terkait penyakit DMT-2, selanjutnya diberikan penjelasan terkait pola aktivitas fisik sebagai upaya pencegahan DMT-2, serta pada tahap akhir diberikan video edukasi mengenai penjelasan infografis tersebut. Pada penyuluhan ini dibuka sesi diskusi sehingga edukasi dapat berjalan efektif. Setelah dilakukan penyuluhan kesehatan, dilakukan follow up menggunakan pesan pribadi di 
WhatsApp. Responden diingatkan untuk selalu hidup sehat serta mendokumentasikan pola perilaku aktivitas fisik yang dilakukan setelah mendapatkan penyuluhan kesehatan.

Pengambilan Data Post Test dan Kuesioner Akhir

Pengambilan data post test dan kuesioner akhir dilakukan dua minggu setelah penyuluhan kesehatan. Data post tes merupakan indikator keberhasilan penyuluhan dari segi perubahan tingkat pengetahuan. Sedangkan data kuesioner akhir digunakan untuk melihat perubahan perilaku aktivitas fisik yang dilakukan responden dalam satu minggu terakhir setelah mendapatkan penyuluhan kesehatan.

\section{Teknik Analisa Data}

Analisa data kuantitatif untuk melihat perbedaan nilai pre test dan post test menggunakan Wilcoxon test yang merupakan alternatif ketika uji-t berpasangan tidak memenuhi asumsi parametrik. Uji ini melibatkan dua pengukuran pada subjek yang sama atas suatu perlakuan tertentu. ${ }^{10}$ Sedangkan uji komparasi yang digunakan untuk melihat adanya peningkatan aktivitas fisik antara sebelum dan setelah dilakukan penyuluhan kesehatan menggunakan Sign test (uji tanda), pada pengujian ini digunakan untuk membandingkan data dua kelompok berpasangan dan data yang digunakan berskala ordinal. ${ }^{10}$ Pada kedua uji tersebut bila hasilnya $p<0,05$ berarti ada perbedaan yang bermakna. ${ }^{10}$

\section{HASIL PENELITIAN \\ Karakteristik Subjek Penelitian}

Pada penelitian ini didapatkan sampel sejumlah 40 orang yang dikarakteristikkan menurut usia, jenis kelamin, dan pekerjaan berdasarkan tingkat pengetahuan dan pola perilaku aktivitas fisik sebelum maupun setelah diberikan penyuluhan kesehatan. Uji statistik menggunakan chi square dengan hasil bermakna bila $p<0,05$ sedangkan $p$ adalah nilai signifikansi yang digambarkan dalam Tabel 2, Tabel 3, Tabel 4 dan Tabel 5 berikut.

Tabel 2. Karakteristik Responden Berdasarkan Tingkat Pengetahuan Sebelum diberikan Perlakuan

\begin{tabular}{|c|c|c|c|c|c|c|}
\hline \multirow[t]{2}{*}{ No. } & \multirow{2}{*}{$\begin{array}{l}\text { Karakteristik } \\
\text { Responden }\end{array}$} & \multirow[t]{2}{*}{$\mathbf{N}(\%)$} & \multicolumn{3}{|c|}{ Tingkat Pengetahuan Awal } & \multirow[t]{2}{*}{$p$} \\
\hline & & & Kurang & Cukup & Baik & \\
\hline \multirow[t]{4}{*}{1.} & Usia (tahun) & & & & & \\
\hline & $40-49$ & $13(32,5 \%)$ & 6 & 7 & 0 & \\
\hline & $50-59$ & $22(55 \%)$ & 7 & 10 & 5 & 0,245 \\
\hline & $\geq 60$ & $5(12,5 \%)$ & 2 & 1 & 2 & \\
\hline \multirow[t]{3}{*}{2.} & Jenis Kelamin & & & & & \\
\hline & Laki-laki & $20(50 \%)$ & 9 & 7 & 4 & 0,442 \\
\hline & Perempuan & $20(50 \%)$ & 6 & 11 & 3 & \\
\hline \multirow[t]{3}{*}{3.} & Pekerjaan & & & & & \\
\hline & Pendidik & $25(62,5 \%)$ & 7 & 12 & 6 & 0,188 \\
\hline & Tendik & $15(37,5 \%)$ & 8 & 6 & 1 & \\
\hline
\end{tabular}

Keterangan: Tabel 2 merupakan karakteristik dari 40 responden dalam presentase jumlah kriteria dibagi jumlah responden dalam kelompok yang sama berdasarkan usia, jenis kelamin, dan pekerjaan dengan tingkat pengetahuan sebelum diberikan perlakuan. Pada klasifikasi tingkat pengetahuan dikatakan baik bila skor $\geq 80$, cukup bila skor $\geq 70$, kurang bila $\leq 50$. Uji statistik menggunakan chi square dengan nilai signifikan bila $\mathrm{p}<0,05$.

Tabel 3. Karakteristik Responden Berdasarkan Tingkat Pengetahuan Setelah diberikan Perlakuan

\begin{tabular}{|c|c|c|c|c|c|c|}
\hline \multirow[t]{2}{*}{ No. } & \multirow{2}{*}{$\begin{array}{l}\text { Karakteristik } \\
\text { Responden }\end{array}$} & \multirow[t]{2}{*}{$\mathbf{N}(\%)$} & \multicolumn{3}{|c|}{ Tingkat Pengetahuan Akhir } & \multirow[t]{2}{*}{$p$} \\
\hline & & & Kurang & Cukup & Baik & \\
\hline \multirow[t]{4}{*}{1.} & Usia (tahun) & & & & & \multirow{4}{*}{0,221} \\
\hline & $40-49$ & $13(32,5 \%)$ & 1 & 7 & 5 & \\
\hline & $50-59$ & $22(55 \%)$ & 1 & 4 & 17 & \\
\hline & $\geq 60$ & $5(12,5 \%)$ & 0 & 2 & 3 & \\
\hline \multirow[t]{3}{*}{2.} & Jenis Kelamin & & & & & \multirow{3}{*}{0,232} \\
\hline & Laki-laki & $20(50 \%)$ & 1 & 9 & 10 & \\
\hline & Perempuan & $20(50 \%)$ & 1 & 4 & 15 & \\
\hline \multirow[t]{3}{*}{3.} & Pekerjaan & & & & & \multirow{3}{*}{0,647} \\
\hline & Pendidik & $25(62,5 \%)$ & 1 & 7 & 17 & \\
\hline & Tendik & $15(37,5 \%)$ & 1 & 6 & 8 & \\
\hline
\end{tabular}

Keterangan: Tabel 3 merupakan karakteristik dari 40 responden dalam presentase jumlah kriteria dibagi jumlah responden dalam kelompok yang sama berdasarkan usia, jenis kelamin, dan pekerjaan dengan tingkat pengetahuan setelah diberikan perlakuan. Pada klasifikasi tingkat pengetahuan dikatakan baik bila skor $\geq 80$, cukup bila skor $\geq 70$, kurang bila $\leq 50$. Uji statistik menggunakan chi square dengan nilai signifikan bila $\mathrm{p}<0,05$. 
Tabel 4. Karakteristik Responden Berdasarkan Perilaku Aktivitas Fisik Sebelum diberikan Perlakuan

\begin{tabular}{|c|c|c|c|c|c|c|}
\hline \multirow[t]{2}{*}{ No. } & \multirow{2}{*}{$\begin{array}{l}\text { Karakteristik } \\
\text { Responden }\end{array}$} & \multirow[t]{2}{*}{$\mathbf{N}(\%)$} & \multicolumn{3}{|c|}{ Aktivitas Fisik Awal } & \multirow[t]{2}{*}{$p$} \\
\hline & & & Ringan & Sedang & Tinggi & \\
\hline \multirow[t]{4}{*}{1.} & Usia (tahun) & & & & & \\
\hline & $40-49$ & $13(32,5 \%)$ & 11 & 1 & 1 & \multirow{3}{*}{0,167} \\
\hline & $50-59$ & $22(55 \%)$ & 17 & 4 & 1 & \\
\hline & $\geq 60$ & $5(12,5 \%)$ & 2 & 3 & 0 & \\
\hline \multirow[t]{3}{*}{2.} & Jenis Kelamin & & & & & \multirow{3}{*}{0,030} \\
\hline & Laki-laki & $20(50 \%)$ & 13 & 7 & 0 & \\
\hline & Perempuan & $20(50 \%)$ & 17 & 1 & 2 & \\
\hline \multirow[t]{3}{*}{3.} & Pekerjaan & & & & & \multirow{3}{*}{0,259} \\
\hline & Pendidik & $25(62,5 \%)$ & 17 & 7 & 1 & \\
\hline & Tendik & $15(37,5 \%)$ & 13 & 1 & 1 & \\
\hline
\end{tabular}

Keterangan: Tabel 4 merupakan karakteristik dari 40 responden dalam presentase jumlah kriteria dibagi jumlah responden dalam kelompok yang sama berdasarkan usia, jenis kelamin, dan pekerjaan dengan pola perilaku aktivitas fisik sebelum diberikan perlakuan. Uji statistik menggunakan chi square dengan nilai signifikan bila $\mathrm{p}<0,05$.

Tabel 5. Karakteristik Responden Berdasarkan Perilaku Aktivitas Fisik Setelah diberikan Perlakuan

\begin{tabular}{|c|c|c|c|c|c|c|}
\hline \multirow[t]{2}{*}{ No. } & \multirow{2}{*}{$\begin{array}{l}\text { Karakteristik } \\
\text { Responden }\end{array}$} & \multirow[t]{2}{*}{$\mathbf{N}(\%)$} & \multicolumn{3}{|c|}{ Aktivitas Fisik Awal } & \multirow[t]{2}{*}{$p$} \\
\hline & & & Ringan & Sedang & Tinggi & \\
\hline \multirow[t]{4}{*}{1.} & Usia (tahun) & & & & & \\
\hline & $40-49$ & $13(32,5 \%)$ & 5 & 7 & 1 & \multirow{3}{*}{0,76} \\
\hline & $50-59$ & $22(55 \%)$ & 5 & 14 & 3 & \\
\hline & $\geq 60$ & $5(12,5 \%)$ & 2 & 3 & 0 & \\
\hline \multirow[t]{3}{*}{2.} & Jenis Kelamin & & & & & \multirow{3}{*}{0,368} \\
\hline & Laki-laki & $20(50 \%)$ & 5 & 14 & 1 & \\
\hline & Perempuan & $20(50 \%)$ & 7 & 10 & 3 & \\
\hline \multirow[t]{3}{*}{3.} & Pekerjaan & & & & & \multirow{3}{*}{0,291} \\
\hline & Pendidik & $25(62,5 \%)$ & 9 & 14 & 2 & \\
\hline & Tendik & $15(37,5 \%)$ & 2 & 11 & 2 & \\
\hline
\end{tabular}

Keterangan: Tabel 5 merupakan karakteristik dari 40 responden dalam presentase jumlah kriteria dibagi jumlah responden dalam kelompok yang sama berdasarkan usia, jenis kelamin, dan pekerjaan dengan pola perilaku aktivitas fisik setelah diberikan perlakuan. Uji statistik menggunakan chi square dengan nilai signifikan bila $\mathrm{p}<0,05$.

Pada penelitian ini didapatkan 40 sampel yang memenuhi kriteria inklusi. Karakteristik responden yang diamati pada Tabel 2, Tabel 3, Tabel 4 dan Tabel 5 antara lain usia, jenis kelamin, dan pekerjaan. Karakteristik berdasarkan usia menunjukkan populasi terbanyak adalah rentang 50 -59 tahun yaitu 55\%, sedangkan populasi terbanyak selanjutnya adalah responden yang berusia rentang 40-49 tahun yaitu $32,5 \%$. Populasi responden paling sedikit adalah berusia $\geq 60$ tahun yaitu sebanyak $12,5 \%$. Usia diketahui tidak memiliki perbedaan dengan tingkat pengetahuan awal $(p 0,245)$ dan akhir $(p 0,221)$. Usia diketahui tidak memiliki perbedaan dengan aktivitas fisik awal $(p 0,176)$ dan akhir ( $p$ 0,762).

Bila dilihat berdasarkan jenis kelamin maka secara keseluruhan populasi responden menunjukkan jenis kelamin laki-laki $50 \%$ dan perempuan $50 \%$. Jenis kelamin diketahui tidak memiliki perbedaan dengan tingkat pengetahuan awal $(p 0,442)$ dan akhir ( $p$ 0,232). Jenis kelamin diketahui memiliki perbedaan dengan aktivitas fisik awal $(p 0,30)$ namun tidak memiliki perbedaan dengan aktivitas fisik akhir (p 0,368).

Selain itu populasi responden berdasarkan pekerjaan terbanyak adalah pendidik yaitu sebesar $62,5 \%$ sedangkan tenaga kependidikan sebesar $37,5 \%$. Pekerjaan diketahui tidak memiliki perbedaan dengan tingkat pengetahuan awal $(p 0,188)$ dan akhir ( $p$ 0,647). Pekerjaan diketahui tidak memiliki perbedaan dengan aktivitas fisik awal $(p 0,259)$ dan akhir ( $p$ 0,291).

\section{Hasil dan Analisa Data Nilai Pre Test dan Post Test}

Uji statistik menggunakan Wilcoxon test dimana hasilnya dikatakan bermakna bila $p<0,05$ yang dapat diamati pada Tabel 6 berikut.

Tabel 6. Uji Wilcoxon Rerata Nilai Pre Test dan Post Test 


\begin{tabular}{lccc}
\hline Variabel & Pre Test & Post Test & $\boldsymbol{p}$ \\
\hline Tingkat & $61,75 \pm$ & $77,25 \pm$ & 0,000 \\
Pengetahuan & 12,58 & 12,40 &
\end{tabular}

Keterangan: Tabel 6 merupakan hasil uji statistik nilai pre test dan post test dalam rata-rata \pm Standar Deviasi (SD) menunjukkan hasil yang signifikan.

Pada uji statistik, secara keseluruhan menunjukkan terdapat 1 orang yang mengalami penurunan nilai post test, dan terdapat 30 orang mengalami peningkatan nilai post test. Selain itu terdapat 9 orang yang memiliki kesamaan nilai pretest dan post test. Adapun rerata nilai tingkat pengetahuan responden mengenai diabetes melitus dan pentingnya melakukan aktivitas fisik dapat diamati pada Gambar 3 berikut ini.

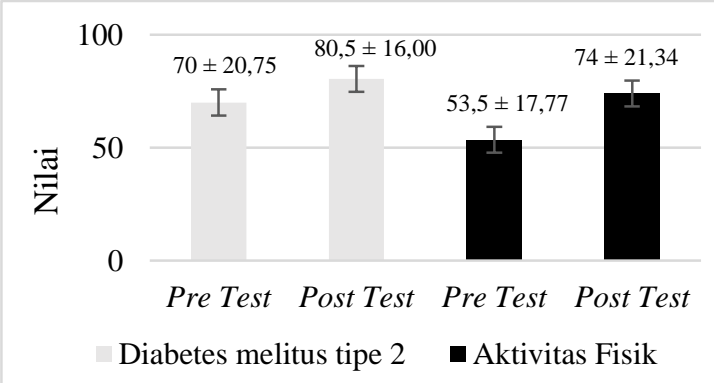

\section{Gambar 3. Tingkat Pengetahuan Responden} Mengenai DMT-2 dan Aktivitas Fisik

Keterangan: Gambar 3 menunjukkan peningkatan pengetahuan responden mengenai diabetes melitus tipe 2 dan pentingnya aktivitas fisik sebagai perilaku pencegahan DMT-2.

Rerata nilai pre test mengenai diabetes melitus yaitu $70 \pm 20,75$ meningkat pada rerata nilai post test menjadi 80,5 $\pm 16,00$ kemudian dilakukan uji Wilcoxon yang didapatkan signifikansi $p 0,027$. Serta rerata nilai pre test mengenai pentingnya melakukan aktivitas fisik yaitu 53,5 \pm 17,77 meningkat pada rerata nilai post test menjadi $74 \pm 21,34$ memiliki signifikansi $p$ 0,000 setelah dilakukan uji Wilcoxon.

\section{Hasil dan Analisa Data Aktivitas Fisik Awal dan Aktivitas Fisik Akhir}

Perbedaan antara perilaku aktivitas fisik sebelum dan setelah diberikan perlakuan dianalisa menggunakan Sign test (uji tanda). Hasil dikatakan terdapat perbedaan yang bermakna bila $p<0,05$ yang dapat diamati pada Tabel 7 berikut ini.

Tabel 7. Uji Tanda (Sign test) Perbedaan Aktivitas Fisik Awal dan Aktivitas Fisik Akhir

\begin{tabular}{|c|c|c|c|}
\hline & \multicolumn{2}{|c|}{ Variabel } & \multirow[t]{2}{*}{$p$} \\
\hline & $\begin{array}{l}\text { Aktivitas } \\
\text { Fisik Awal } \\
\text { (N) }\end{array}$ & $\begin{array}{l}\text { Aktivitas } \\
\text { Fisik Akhir } \\
\text { (N) }\end{array}$ & \\
\hline Rendah & 30 & 12 & \multirow[t]{3}{*}{0,000} \\
\hline Sedang & 8 & 24 & \\
\hline Tinggi & 2 & 4 & \\
\hline
\end{tabular}

Keterangan: Tabel 8 merupakan perbedaan jumlah responden yang melakukan aktivitas fisik sesuai tingkatannya sebelum dan setelah diberikan perlakuan, $\mathrm{N}$ merupakan jumlah responden sedangkan $p$ merupakan signifikansi.
Pada uji tanda (Sign test) secara keseluruhan menunjukkan terdapat 1 orang mengalami penurunan aktivitas fisik setelah dilakukan penyuluhan kesehatan, 19 orang mengalami peningkatan aktivitas fisik setelah dilakukan penyuluhan kesehatan, serta 20 orang memiliki kesamaan aktivitas fisik sebelum dan setelah dilakukan penyuluhan kesehatan.

\section{PEMBAHASAN}

\section{Karakteristik Responden Menurut Usia}

Pada penelitian ini responden terbanyak berusia 50-59 tahun. Uji statistik menunjukkan hasil yang tidak signifikan antara usia dengan tingkat pengetahuan sebelum maupun setelah diberikan penyuluhan. Hal ini sejalan dengan penelitian Wardani et al (2014) bahwa tidak ada perbedaan tingkat pengetahuan seseorang dengan usia. Tidak adanya hubungan antara usia dengan tingkat pengetahuan dapat disebabkan karena rentang perbedaan usia responden yang tidak terpaut jauh selain itu terdapat faktor yang dapat menghambat proses belajar pada orang dewasa yaitu penurunan pendengaran dan penglihatan yang menyebabkan gangguan kekuatan untuk berpikir. ${ }^{11}$ Namun hal ini tidak sesuai dengan pendapat Budiman (2013) bahwa salah satu faktor yang dapat mempengaruhi tingkat pengetahuan yaitu usia karena seiring dengan bertambahnya usia, maka akan semakin berkembang daya tangkap dan pola pikir seseorang. ${ }^{12}$

Usia tidak memiliki hasil yang bermakna dengan pola perilaku aktivitas fisik sebelum maupun setelah diberikan penyuluhan pada uji statistik. Hal ini didukung oleh Riskawati et al (2018) bahwa usia tidak berhubungan terhadap aktivitas fisik, karena perilaku aktivitas fisik merupakan kebiasaan seseorang yang telah ditanamkan sebelumnnya. ${ }^{13}$ Selain itu hal ini sesuai dengan penelitian Abadini dan Wuyaningsih (2019) bahwa faktor usia tidak memiliki perbedaan dengan perilaku aktivitas fisik. ${ }^{2}$

Karakteristik Responden Menurut Jenis Kelamin

Responden laki-laki dan perempuan berjumlah sama. Uji statistik menunjukkan hasil yang tidak bermakna antara jenis kelamin dengan tingkat pengetahuan sebelum maupun setelah diberikan penyuluhan. Tidak terdapatnya hubungan antara jenis kelamin dan pengetahuan seseorang sesuai dengan penelitian Suwaryo dan Yuwono (2017) bahwa belum ada penjelasan jenis kelamin apa yang memiliki tingkat kognitif lebih baik. ${ }^{15}$ Menurut Ifada (2010) jenis kelamin tidak mempengaruhi tingkat pengetahuan dikarenakan pada zaman sekarang tidak ada perbedaan berdasarkan jenis kelamin untuk memperoleh kesempatan dalam belajar. ${ }^{16}$

Sedangkan hasil yang bermakna ditemui pada perbedaan jenis kelamin dan aktivitas fisik sebelum diberikan penyuluhan yang pada penelitian ini perempuan lebih banyak melakukan aktivitas intensitas tinggi daripada laki-laki. Sejalan dengan penelitian Abadini dan Wuryaningsih (2019) bahwa variabel yang berpengaruh pada aktivitas fisik adalah jenis kelamin. ${ }^{2}$ Namun berbeda setelah diberikan 
penyuluhan, jenis kelamin tidak memiliki perbedaan dengan aktivitas fisik sesuai pernyataan Riskawati et al (2018) bahwa aktivitas fisik tidak dipengaruhi oleh jenis kelamin karena pada dasarnya laki-laki maupun perempuan memiliki kegiatan yang hampir sama. ${ }^{13}$ Karakteristik Responden Menurut Pekerjaan

Pada penelitian ini populasi pendidik lebih banyak dari pada jumlah populasi tenaga kependidikan. Uji statistik menunjukkan tidak adanya perbedaan antara pekerjaan dengan tingkat pengetahuan sebelum maupun setelah diberikan penyuluhan. Menurut Ifada (2010) pekerjaan bukan faktor utama untuk memperoleh pengetahuan melainkan dapat diperoleh dari keluarga, masyarakat maupun lingkungan. ${ }^{16}$ Didukung oleh Wardani et al (2014) dimana pekerjaan tidak berhubungan dengan tingkat pengetahuan, hal ini dikarenakan rata-rata secara keseluruhan pendidik dan tenaga kependidikan memiliki tingkat pendidikan dan pengalaman yang hampir sama dalam bekerja. ${ }^{11}$

Selain itu pekerjaan juga tidak berhubungan dengan perilaku aktivitas fisik sebelum maupun setelah diberikan penyuluhan pada uji statistik. Ahmad et al (2019) mengungkapkan pekerjaan tertentu tidak berhubungan dengan perilaku aktivitas fisik seseorang. ${ }^{17}$ Menurut Abadini dan Wuryaningsih (2019) pendidik dan tenaga kependidikan adalah pekerja kantor yang cenderung memanfaatkan teknologi untuk bekerja dan memiliki durasi jam kerja yang panjang sehingga kurangnya kesempatan untuk melakukan aktivitas fisik. ${ }^{2}$

\section{Perbedaan Tingkat Pengetahuan Setelah Penyuluhan Kesehatan}

Analisa statistik menggunakan uji Wilcoxon yang menunjukkan hasil signifikan antara rata-rata nilai pre test dan post test pendidik dan tenaga kependidikan Perguruan Tinggi di Malang. Uji ini dipilih sebagai alternatif karena uji-t berpasangan tidak memenuhi asumsi parametrik setelah dilakukan uji normalitas. Pada penelitian ini menjelaskan adanya perbedaan tingkat pengetahuan pendidik dan tenaga kependidikan di UNISMA setelah penyuluhan kesehatan sebagai upaya pencegahan diabetes melitus tipe 2. Hal ini sejalan dengan penelitian Huznah dan Azria (2016) yaitu terdapat perbedaan tingkat pengetahuan antara sebelum dan setelah dilakukan penyuluhan kesehatan ditandai oleh nilai post test menjadi lebih baik daripada nilai pre test. ${ }^{18}$ Didukung oleh Kusumawardani et al (2012) yang menjelaskan penyuluhan kesehatan dapat meningkatkan pengetahuan seseorang ditandai oleh peningkatan skor post test. ${ }^{19}$ Penyuluhan kesehatan merupakan pendidikan non formal dalam rangka upaya merubah kehidupan masyarakat menjadi lebih sehat. ${ }^{20}$ Semakin banyak informasi yang masuk maka semakin banyak tingkat pengetahuan yang didapatkan tentang kesehatan. ${ }^{12}$

Dalam teori Benjamin Samuel Bloom dijelaskan bahwa tujuan pendidikan terbagi dalam tiga ranah yaitu kognitif, afektif dan psikomotorik. Meningkatnya pengetahuan oleh responden merupakan aplikasi dari salah satu kategori ranah kognitif dalam taksonomi Bloom yaitu "knowledge". Pada tahap kategori ini seseorang memiliki kemampuan mengingat hal yang pernah dipelajari sebelumnya dan mampu menuangkannya dalam menjawab pertanyaan seputar hal tersebut berdasarkan ilmu pengetahuan yang telah dimiliki. ${ }^{21}$

Kemampuan mengingat adalah sebuah pengalaman yang diperoleh seseorang setelah melalui proses pembelajaran. ${ }^{25}$ Pada penelitian ini intervensi penyuluhan kesehatan diberikan menggunakan infografis dan video edukasi karena mengacu pada kerucut pengalaman yang dijelaskan oleh Edgar Dale dalam Notoatmodjo (2008), dimana media komunikasi yang efektif dan dapat diingat yaitu menggunakan infografis dan video edukasi sebanyak $50 \%$. Selain itu dalam intervensi ini ditambahkan dengan diskusi sehingga pengalaman seseorang meningkat hingga $70 \%$. Kemampuan seseorang dalam mengingat sebuah pengalaman dapat dilihat kurang lebih setelah dua minggu. ${ }^{25}$

Selain bertujuan untuk meningkatkan pengetahuan, penyuluhan kesehatan yang diberikan dapat menimbulkan rasa sadar dalam diri untuk mengaplikasikannya dalam kehidupan sehari-hari. ${ }^{24}$ Hal tersebut terbukti dalam penelian ini yang menunjukkan tingkat pengetahuan responden mengenai DMT-2 dan pentingnya melakukan aktivitas fisik menyebabkan perubahan perilaku responden menjadi lebih aktif untuk bergerak. Sesuai dalam ranah kognitif yang terdapat dalam Taksonomi Bloom, pada tahap ini responden telah melewati kategori "knowledge" yaitu pengetahuan dan memasuki kategori "comprehension" yaitu pemahaman makna yang sedang dipelajari kemudian melakukan "application" yaitu penerapan konsep yang telah dipelajari. ${ }^{21}$ Semakin meningkatnya pengetahuan responden mengenai DMT-2 dan pentingnya melakukan aktivitas fisik maka meningkat pula penerapan upaya pencegahan DMT-2 dalam kehidupan sehari-hari.

\section{Pengaruh Penyuluhan Terhadap Pola Perilaku Aktivitas Fisik}

Analisa statistik menggunakan Sign test (uji tanda) menunjukkan hasil yang signifikan antara pola perilaku aktivitas fisik sebelum dan setelah diberikan perlakuan. Hal ini menjelaskan bahwa pola perilaku aktivitas fisik seseorang meningkat setelah diberikan penyuluhan kesehatan. Penilaian aktivitas fisik menggunakan kuesioner GPAQ (Global Physical Activity Questionnaire) berdasarkan aktivitas fisik responden dalam satu minggu terakhir setelah diberikan penyuluhan yang dikonfirmasi responden menggunakan dokumentasi saat melakukan aktivitas fisik.

Hasil ini sejalan dengan penelitian yang dilakukan oleh Anandika dan Hidayat (2015) bahwa ternyata penyuluhan kesehatan dapat mengubah baik pola perilaku dan sikap seseorang akibat ilmu pengetahuan yang didapatkannya. Pengetahuan merupakan aspek yang penting untuk membentuk tindakan seseorang. ${ }^{22}$ Huznah dan Azria (2016) menyimpulkan bahwa penyuluhan kesehatan dapat 
mempengaruhi pengetahuan, sikap, dan perilaku seseorang untuk memilih tindakan yang lebih baik dalam rangka upaya menjaga kualitas kesehatan. ${ }^{18}$ Selain itu intelegensia dan kemampuan berpikir juga dapat mempengaruhi seseorang untuk menerapkan pengetahuan dalam tindakan nyata sesuai dengan konsep Health Belief Model (HBM) dimana pola perilaku sehat ditentukan oleh kepercayaan masingmasing individu. ${ }^{23}$ Perubahan perilaku menjadi lebih baik pada diri responden merupakan aplikasi dimensi dalam teori HBM yaitu adanya pengetahuan mengenai bahaya timbulnya suatu penyakit menimbulkan motivasi untuk selalu hidup sehat (Health motivation). ${ }^{23}$

Ranah afektif dalam Taksonomi Bloom yang menekankan sikap maupun aspek emosional dapat menjelaskan bahwa responden telah melewati kategori "receiving" yaitu penerimaan terhadap informasi yang diperoleh, kemudian memasuki tahap "responding" yang berarti memiliki kemampuan berpartisipasi dan termotivasi serta "valuing" yaitu dapat menilai suatu hal yang baik dan diterapkan dalam perilaku. ${ }^{21}$ Perubahan pola perilaku dapat diperoleh seseorang setelah melalui proses belajar sesuai dengan teori behavioristik. ${ }^{14}$ Pada penelitian ini intervensi penyuluhan diberikan sebanyak tiga kali secara bertahap sesuai konsep behavioristik yang diungkapkan oleh Roger dalam Asfar et al (2019) bahwa pemberian informasi diperlukan berulang kali untuk dapat merubah perilaku seseorang. ${ }^{14}$

Adapun kekurangan dalam penelitian ini yaitu pengambilan data yang mengandalkan kuesioner sebagai data primer sehingga terdapat bias yang sulit untuk dikendalikan. Salah satu cara untuk mengendalikan bias tersebut dengan melakukan follow up kepada responden untuk mendapatkan informasi tambahan yang diharapkan dapat mengkonfirmasi perubahan perilaku yang dilakukan oleh responden. Selain itu kurangnya jumlah responden yang didapatkan dalam penelitian ini menyebabkan perbedaan pada karakteristik responden menjadi tidak signifikan. Hal ini dapat disebabkan karena masyarakat yang menolak dalam mengisi survei serta kurangnya kepedulian terhadap kualitas kesehatan dirinya.

\section{KESIMPULAN}

Berdasarkan hasil penelitian ini dapat disimpulkan sebagai berikut :

1. Terdapat peningkatan pengetahuan mengenai DMT-2 dan pentingnya melakukan aktivitas fisik setelah penyuluhan aktivitas fisik pada pendidik dan tenaga kependidikan di UNISMA.

2. Terdapat peningkatan pola perilaku aktivitas fisik setelah penyuluhan aktivitas fisik pada pendidik dan tenaga kependidikan di UNISMA sebagai upaya pencegahan DMT-2.

\section{SARAN}

Berdasarkan pembahasan dari penelitian ini, peneliti menyarankan untuk :
1. Peneliti menyarankan untuk memberikan jangka waktu yang lebih lama dalam memberikan kesempatan kepada responden untuk menciptakan perubahan pola perilaku.

2. Disarankan untuk mengembangkan metode penyuluhan yaitu dilakukan secara langsung disertai observasi dan pelatihan secara menyeluruh, sehingga dapat meningkatkan pengetahuan akan pentingnya melakukan aktivitas fisik dalam rangka meningkatkan kualitas kesehatan masyarakat.

3. Disarankan untuk menambah jumlah responden agar hasil yang diperoleh pada karakteristik responden menjadi signifikan.

4. Peneliti menyarankan pada penelitian selanjutnya dalam melakukan upaya skrining dapat menggunakan pemeriksaan kadar gula darah meliputi GDP (gula darah puasa) atau GD2PP (gula darah 2 jam post prandial) atau kadar HbA1c.

5. Peneliti menyarankan hasil penelitian ini menjadi landasan untuk diadakan penelitian lanjutan terkait seberapa besar tingkat pengetahuan dapat mempengaruhi pola perilaku masyarakat.

6. Pada penelitian selanjutnya disarankan untuk menggunakan pendekatan HBM (Health Belief Model).

\section{UCAPAN TERIMAKASIH}

Terimakasih disampaikan kepada Ikatan Orang Tua Mahasiswa dan Fakultas Kedokteran Universitas Islam Malang yang telah mendukung dan mendanai penelitian ini.

\section{DAFTAR PUSTAKA}

[1] Zamroni, Mohammad. Perkembangan Teknologi Komunikasi dan Dampaknya Terhadap Kehidupan. Yogyakarta : Jurnal Dakwah. 2009. $10.2: 195-199$.

[2] Abadini, D dan Wuryaningsih, C.E. Determinan Aktivitas Fisik Orang Dewasa Pekerja Kantoran di Jakarta Tahun 2018. Fakultas Kesehatan Masyarakat Universitas Indonesia: Jurnal Promosi Kesehatan Indonesia. 2019. 14.1:1528.

[3] Nurayati, L dan Adriani, M. Hubungan Aktifitas Fisik dengan Kadar Gula Darah Puasa Penderita Diabetes Melitus Tipe 2. Journal of Amerta Nutrition. 2017. 1.2: 80-87.

[4] World Health Organization. Diabetes Facts Sheet. 2018. (diunduh Februari 2020). Tersedia dari: $\quad$ http://www.who.int/news-room/factsheets/detail/diabetes.

[5] Trisnawati, S.K., dan Setyorogo, S . Faktor Risiko Kejadian Diabetes Melitus Tipe II di Puskesmas Kecamatan Cengkareng Jakarta Barat Tahun 2012. Jakarta : Jurnal Ilmiah Kesehatan. 2013. 5.1: 6-10.

[6] Goenawan, H., Tarwan, V.M., Sylviana, N., Nurhayati, T., Fatimah, S.N., Lesmana., et al. Gambaran Pengetahuan Tentang Pentingnya 
Aktivitas Fisik Sebagai Pencegah Sindrom Metabolik Pada Staf Perguruan Tinggi di Jawa Barat. Bandung: Jurnal Fakultas Kedokteran, Universitas Padjadjaran. 2018. 2.4 : 1-3.

[7] Nurmalitta, Esty Dwi. Hubungan Antara Aktivitas Fisik pada Siswa-siswi Overweight dengan Kualitas Hidup di SMA Negeri 1 Jember. Jember: Jurnal Fakultas Kedokteran Universitas Jember. 2017.

[8] Mahmud. Metode Penelitian Pendidikan. Bandung: CV Pustaka Setia. 2011.

[9] Sugiono, S. Metode Penelitian Kuantitatif Kualitatif dan R\&B. Bandung: Alfabeta. 2012.

[10] Syahdrajat, Tantur. Panduan Penelitian Untuk Skripsi Kedokteran dan Kesehatan. Jakarta: Rizky Offset. 2019.

[11] Wardani, N.I.I., Rejeki, D.S.S dan Masfiah, S. Faktor-faktor yang berhubungan dengan tingkat pengetahuan kader kesehatan tentang thalassaemia di Kecamatan Sumbang Kabupaten Banyumas. Kesmas Indonesia: Jurnal Ilmiah Kesehatan Masyarakat. 2014. 6.3: 194-206.

[12] Budiman, Riyanto Agus. Kapita selekta kuesioner pengetahuan dan sikap dalam penelitian kesehatan. Jakarta: Salemba Medika. 2013. 66-69.

[13] Riskawati, Y.K., Prabowo, E.D dan Al Rayid, H. Tingkat Aktivitas Fisik Mahasiswa Program Studi Pendidikan Dokter Tahun Kedua, Ketiga, Keempat. Jurnal Kesehatan FKUB. 2018. 5.1: 27-32.

[14] Asfar, A.M.I.T., Asfar, A.M.I.A dan Halamury, M.F. Teori Behaviorisme. Makasar: Program Doktoral Ilmu Pendidikan. Universitas Negeri Makassar. 2019.

[15] Suwaryo, P.AW dan Yuwono, P. Faktor-Faktor Yang Mempengaruhi Tingkat Pengetahuan Masyarakat dalam Mitigasi Bencana Alam Tanah Longsor. URECOL. 2017. 305-314.
[16] Ifada, I. Faktor-Faktor Yang Berhubungan dengan Pengetahuan Masyarakat Mengenai Pelayanan Kesehatan Mata. PhD Thesis. Faculty of Medicine. 2010.

[17] Ahmad, F. Rahayu, M. A., Putri, A. L. A., Ulfani, A. R., Siti, Z., \& Wijayanti, E. Hubungan Status Pekerjaan dengan Aktivitas Fisik pada Keluarga Binaan di Desa Pangkalan RT 09/03 Kecamatan Teluk Naga dan Desa Kemuning RT 11/03 Kecamatan Kresek, Kabupaten Tangerang, Provinsi Banten. Jurnal Kesehatan Pharmamedika. 2019. 11.1.

[18] Azria, C.R dan Huznah, H. Pengaruh Penyuluhan Gizi Terhadap Pengetahuan dan Perilaku Ibu Tentang Gizi Seimbang Balita Kota Banda Aceh. Jurnal Kedokteran Syiah Kuala. 2016. 16.2: 88-94.

[19] Kusumawardani, E., Akhaesi, N. dan Hardian, H. Pengaruh penyuluhan kesehatan terhadap tingkat pengetahuan, sikap dan praktik ibu dalam pencegahan demam berdarah dengue pada anak. 2012. PhD Thesis. Fakultas Kedokteran.

[20] Waryana. Promosi Kesehatan, Penyuluhan dan Pemberdayaan Masyarakat. Yogyakarta: Nuha Medika. 2016.

[21]Dimyati dan Mudjiono. Belajar dan Pembelajaran. Jakarta: Rineka Cipta. 2009.

[22] Anandika, Widya dan Hidayat, A. Penyuluhan terhadap Perilaku Stimulasi Tumbuh Kembang pada Ibu di PAUD Tapak Dara Bangunjiwo Kasihan Bantul. 2015. PhD Thesis. STIKES'Aisyiyah Yogyakarta.

[23] Abraham, Charles dan Sheeran, P. The Health Belief Model. Predicting health behaviour. 2005. 2: 28-80.

[24] Yaumi, Muhammad. Prinsip-Prinsip Desain Pembelajaran. Jakarta: Kencana. 2013.

[25] Notoatmodjo, S. Metodologi Penelitian Kesehatan. Edisi Revisi. Jakarta: PT Rineka Cipta. 2008. 
Suplementary 1. Kuesioner GPAQ WHO dapat diakses pada tautan berikut :

$\underline{\text { https://bit.ly/kuesionergpaqwho }}$

Suplementary 2. Soal Pre Test dan Post Test dapat diakses pada tautan berikut :

https://bit.ly/pretestpenelitiann dan

https://bit.ly/postestpenelitian

Suplementary 3. Tabel Morgan and Krecjie dapat diakses pada tautan berikut :

http://bit.ly/tabelmorganandkrecji

Suplementary 4. Infografis Penyuluhan Kesehatan dapat diakses pada tautan berikut :

http://bit.ly/posterdmt2 dan

http://bit.ly/posteraktivitasfisik

Suplementary 5. Video Penyuluhan Kesehatan dapat diakses pada tautan berikut :

http://bit.ly/videoedukasicegahdm 